Gerald P. Dwyer, Jr. and R. W. Hafer

Gerald P. Dwyer, Jr, associate professor of economics, University of Houston, is a visiting scholar and $R$. W. Hater is a research officer at the Federal Resene Bank of St. Louis. Nancy D. Juen and Rosemarie V. Mueller provided research assistance.

\title{
Are National Stock Markets Linked?
}

A markets have become more integrated in recent years. This process began with the relaxation of controls on capital movements in the $1950 \mathrm{~s}$ and was followed, during the last decade or so, by the gradual relaxation of exchange controls. Recently, substantial improvements also have been made in computer and communication technology that have lowered the cost of international information flows and cross-border financial transactions.'

This globalization of financial activities has led some to argue that the behavior of stock prices in 1987 was influenced by international events to a greater extent than anyone had thought previously. For example, in its discussion of 1987 , the report by the Presidential Task Force on Market Mechanisms commonly known as the Brady Commission suggests that "investors made com parisons of valuations in different countries, often using higher valuations in other countries as justification for investing in lower valued markets. Consequently, a process of ratcheting up among worldwide stock markets began to develop." In other words, a higher level of prices in one market increased the level in other makets. As for the fall in prices, the Brady Commission report notes that "Iwhat may have appeared strictly a 'Wall street" collapse was the result of the cumulative impact of several developments occurring simultaneously in several other financial centers.":

There appeas to be no one reason that explains the worldwide decline in equity values during October 1987. The timing and magnitude of the declines differed across markets around the world. Even so, all of the organized makets fell. This coincident fall suggests that changes in the markefs are indeed related to one another.

The behavior of stock prices since the October crash suggests that markets around the world do not move in tandem. As interpreted by Cowan 1988), "the first quarter of 1988, if nothing else, dispelled the popular notion that there is one synchronized, global market." While stock prices in the United States were 9.8 percent below their value on Oclober 16 , stock prices in Japan were
Cooper (1986) and Bryant (1987) discuss these and related issues.

2Presidential Task Force on Market Mechanisms (1988), p. 10.

Ibid. Study 1, p. 2. Most of the reasons offered in the report to explain the decline, however, are related to economic developments in the Uniled States of changes in the dollar's value in foreign exchange markets. The primary reasons for the break in equity prices given are: the persistent and large budget and trade deficits in the United States; instability in foreign exchange markets, stemming primarily from the continued fall in the dollar after the Louvre accord; the international rise in interest rates; and the threatened end to takeovers in the United States. For more, see ibid., Study I, pp. 11-13.

${ }^{4}$ Roll (1988) provides an analysis of the different markets behavior. 
only 0.4 percent below their pre-crash level by the fod of the first quarter. The Geman stock price index at the end of March 1988. in contast was 28.3 percent below its pre-crash level. While some makets had recovered some or all of their October 1987 loss, others clearly had not.

These dispanate movements laise questions about just how the different stock malkets around the world are felated. Given the increase in Japanese stock prices since the chash, should we be surprised not to have had a similar rise in the United States? Or is it really unusuat for all mal" kets to move together as they did duing the week of October $19,198 \%$ ?

In this article, we examine the statistical rela tionship between the levels and movements of stock price indexes for Gemany, Japan, the United Kingdom and the United States, using daily data for July 1987 through Januay 1988 and monthy data for the past 31 years. Thus, we can examine the relationships both over a shor period encompassing the October crash and across a longer horizon, in order to put the events of last year into some long-un perspective.

\section{HOW SHOULD STOCE PPITLES PH WINKCD?}

In standard models of stock price detemination, the level of a stock's price equals the present value of expected future dividends. Anything that changes the fundamentals - that is, the expected future dividends or the interest rate at which those dividends are discounted - affects the price of the stock:

One way of thinking about linkages across national stock markets is to start with an extreme form of linkage and to examine what loosens these links. Suppose that the transaction costs of buving and seling stocks and foreign exchange anywhere in the world are zero. Suppose also that investors are risk-neutral that is, stockholders are indifferent to holding different stocks only if they yield the same expected retum. For all stocks in the world to be held, the expected retum in terms of any common curency must be the same for holding any stock anywhere in the word. This idea can be written as
(1) $\mathrm{En}_{\mathrm{i}, \mathrm{f}}=\mathrm{EH} n_{\mathrm{i}, \mathrm{H}}+\mathrm{E} \Delta \mathrm{e}_{1}$

where $\mathrm{Eh}_{\mathrm{i}, \mathrm{s}}$ is the expected rate of return from holding a slock in country in tems of is cur. rency in period $t, \mathrm{Eh}_{\mathrm{i}, 3}$ is the expected rate of recum from holding a stock in country in terms of is currency and $\mathrm{E} \Delta \mathrm{e}$, is the expected rate of change in the price of counlyy j's currency in terms of county i's curency. For convenience, we can call this relationship "stock retum parity, "if it existed, stock return parity would imply that the expected return from holding stock of a comestic firm is the same as the expected return from holding the stock of a foreign firm.

\section{Hinhages of price wewels}

Even if slock return parity holds, unexpected vents will guanante that there will be no reliable relationship between the levels of various stocks' prices, even in the same currency. For example, suppose there is an unexpected permanent increase in the demand for Hondas relative to Fords which increases the expected eanings and dividends of Honda relative to Ford. Because of the change in expected dividends, the price of Honda stock will increase relative to the price of Ford stock. This will occur even with stock retum par" ity. An unexpected increase in the price of Honda stock produces a capital gain, which means that the ex post rate of retum from holding Honda stock will be higher than from holding Ford stock. This is perfectly consistent with stock return pasity, which holds that the expected rates of retum are the same both now and in the future. Moreover, once the price of Honda stock increases, we should hardly expect that the price of Ford stock will rise just because the price of stock in Fonda is higher. This analysis holds both for companies in the same national market and for companies in different national markets. Infemationally, even though financial markets may be increasingly inte grated, the relative levels of stock prices for indexes of stock prices around the wonld will diverge, because they represent the valuation of different firms.

The preceding argument can be demonstrated more formaly. In tems of $x_{3}$ post mates of retur. equation 1 car be written as

(2) $h_{i, t}=h_{i, 1}+\Delta e_{1}+\epsilon_{i, 1}-\epsilon_{i, 1}-\epsilon_{i, t}$,

\footnotetext{
sThe mator alternative to models based on the fundamentals is known as a rational bubble model. Essentially, this model allows prices to deviate from that predicated on the fundamentals. For a discussion of the differences between these models, see Santoni (1987) and Santoni and Dwyer (1988).
}

6In effect, this is uncovered interest parity applied to stocks. We

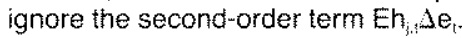

If firms have firm-specific capital, the relative change in price levels car be permanent. 
Whate $\epsilon_{\mathrm{i}-1}$ is the unexpected part of the holding period retum for stock in period $t, \epsilon_{i, k}$ is the unexpected part of the holding period aeturn for stock $j$ and $\epsilon_{1.2}$ is the unexpected pant of the rate of change of the exchange rate. If expectations are rational in the sense of Muth (1961), then the E's are independent of the expected past of the holding period returns." Assume that the variances and covarim ances of the $\epsilon$ 's are constant. If we assume that dividends are zero, then equation 2 can be written as

$$
\begin{aligned}
& \text { (3) } p_{i, l+1}-p_{i, \xi}=p_{i, k+1}-p_{i, k}+e_{i+1}-e_{1}+\epsilon_{i, k} \\
& -\epsilon_{i, 1}-\epsilon_{i, 1}
\end{aligned}
$$

where $p$ is the logarithm of the price of the stock, $e$ is the logarith of the exchange mate and the subscript $1+1$ denotes the price one period in the fiture. Reamanging terms, equation 3 can be wit ten as

(a) $p_{i, 1+1}-p_{i, 1+1}-e_{i+\xi}=p_{i, 1}-p_{i, 1}-e_{1}+\epsilon_{i, 1}$

$$
-\epsilon_{i, 1}-\epsilon_{i, s}
$$

Defme $x=p_{i}-p_{i}-e$. Then equation 4 can be rewritten as

(5) $x_{i+1}=x_{i}+\epsilon_{i, 1}-\epsilon_{i .1}-\epsilon_{i: 1.1}$.

Equation 5 shows that relative stock prices next period simply are equal to relative stock prices this period plus the difference between the lnexpected parts of the holding period retums $\epsilon_{i, t}-$ $\epsilon_{i .1}$ and the unexpected change in the exclange rate $\left\{\epsilon_{i, t}\right\}$. In other woads, even if expected rates of return are identical, relative stock prices in terms of a common culency are a random walk. When the relative stock price indexes lake a random step up or down, the relative slock prices show no tendency to refum to any paticular value.

This is impotant because it means that, even if the expected holding period returns of two stocks were perfectly correlated, the levels of the prices will show no stable relationship. Because relative stock prices are characterized as random walks, correlations between the levels of national stock price indexes are unstable. The levels of stock prices in different markets may rise of fall together, or move in opposite directions. Moreover', the size of correlations of the stock price levels will depend on the sample period used and the unexpected changes in the two counues stock prices and exchange rates in that period.

Another way of thinking about a time-series process that is a random wak is in terms of a "unit root." Alhough a random walk is a particular kind of unitroot process, the two are not svnonymous. While its evolution may have additional components, a unitroot series wanders around in the same way that a random wak does. For example, neither a random walk nor a unit-root process has a tendency to retun to any particular value over time. The algebrabove has been simplified consideably by assumptions that make the relative stock price indexes a random walk. Rather than maintain these assumptions for example. constan variances of the unexpected parts of the returns from holding slocks and the changes in the logarithm of the exchange ratel, we directly test for unit roots in the empirical analysis.

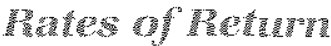

Stock retum party, while useful for making the point above, is illustrative mather than descriptive. Stock refun parity implies that, since the expected rates of return from holding different stocks are the same, the correlation of expected returns is one. It is unlikely that stock return parity holds. If stock neturn parity holds acloss national borders, it should hold within a country as well; this means that differences between the expected returns on domestic stock should be unpredictable. This prediction, however is inconsistent with the data."

Factors Decreasing the Correlations - Evi* dence indicates that expected returis from holding stock in both the United States and other

${ }^{5}$ Actually, the only implication that we need is that the expected

1TSee Malkiel (1985). part of the holding period return and the unexpected part are uricorrelated.

${ }^{9}$ The precise definition of a unit root is based on the atutoregressive representation of a series. It the fundamental movingaverage representation of a series, say $x$, has an autoregressive representation, then it can be witten as

$[1 \cdots \alpha(L)] X_{1}=\epsilon_{1}$,

where $L$ is the lag operator such that $L x_{1}=x_{t-1}$ and $\alpha(L)=$

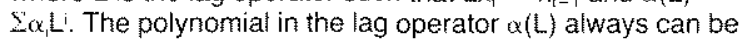
wrtten as $\alpha(L)=(1 \cdots \beta, L) B(L)$. If there exists a root $B$, that is equal to one, then the series $x$ is said to have a unit root. 
countries are related to the riskiness of holding slock relative to other financial assets. To the extent that the variability of the return from holding a stock cannot be diversified away, expected rates of retum are higher for 'iskier stocks." This finding suggests that stock return parity is unlikely to hold. Expected rates of return differ across firms and industries; avalable evidence suggests that country risk also is important,

There also are transaction costs associated with buying and selling stocks. Today, explicit transaction costs are relatively unimportant in buving and selling large blocks of stock around the world. With implovernents in communication and the ability to order trades over phone lines, the explicit cost to someone in London of buying AT\&T stock in New York is little mone than the cost to someone in New York.

Nonetheless, government restrictions are part of the costs of executing a transaction, and these restrictions have been important at times in executing intemational transactons. Exchange controls were one of the ways that countries maintained the fixed-exchange-iate regime in place until 1973. By limiting access to foreign exchange, govemments sought to manipulate the demand for their currency relative to foreign currency, thereby assisting their attempts to maintain a fixed exchange rate. In some cases, governments also restricted foreigners' ability to purchase domestic financial assets. Both types of controls have been declining gradually since the demise of fixed exchange rates.

Factors Increasing the Correlations - Some forces make expected returns in different countries posifively related even if there were no international financial transactions. If the demand fo: automobiles increases in the United States, which increases the expected earnings and dividends of domestic automobile companies, it also can increase the expected earnings of automobile companies like Honda, which are headquartered in Japan and sell automobiles in the Enited States. Consequently, changes in stock prices in the
United States and Japan can be positively correlated even if no foreigner an buy stock in eithes conntry. This example, while trivial in some nespects, points out that international rade creates a link between at least some stocks in different makkels.

In addition to trade, multinational operations by firms create links through ownership of real assets that can affect firms headquartered in different countries. For example, ford manufactures autonobiles in Europe. A recession in Europe would likely decrease the demand fo: Ford antomobiles and lower Ford's eamings, dividends and stock price on the New York Stock Exchange.

Finally, relative to data on individual firms' shares, stock index data will have a highes correlation than the corelation of retums from tandomy selected stocks on different markets. All of the actual data that we use below are indexes of stock prices. Consequently, the indexes average out much of the variation attributable to individual fims or industries. Thus, if there were no factors that differentially affect firms in different countries, the expected retums in any common currency measured by these indexes would be virtur ally the same.

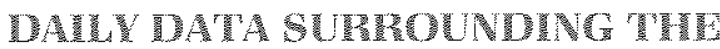 CPASH}

In this section, we examine daily values of stock price indexes for seven months surrounding the crash for evidence of the "ratcheting up" in stock makets suggested by the Brady Report. Dally values of stock price indexes from Germany, Japan, the United Kingdom and the United States for July 1, 1987, through January 29,1988 , are used." This petiod includes three months before the October 1987 crash and thee months after it. To make the relative values of the indexes comparable, all of the measures are set to a base value of 100,0 on July 1 , 1987. Because the markets are open in daylight hours in different time zones, the markets in our sample are not all open at the same time. We

\footnotetext{
1Malkiel ( 1985 ) summarizes the evidence. The riskiness of a firm's stock can be divided into its relationship with general movements in the market (market risk) and the factors that cause it to deviate from the markel (non-market risk). Nonmakket risk includes those factors that influence a specific firm or industry. The tdea that there are lactors that cause tirms or industry groupings of firms to deviate from the market portfolo applies also to the divergent movements of national stock price indexes.

2See Solnik (1974); Cho, Eun and Senbet (1986).
}

sor an annual discussion of changes in these controls on a country-by-country basis, see ary issue of the International Monetary Fund's Exchange Arrangements and Exchange Restrictions.

1. The daily stock market indexes, both in terms of local currency and U.S. dollars, afe from Morgan Stantey's Capital Interna tional Perspective. The indexes are market-weighted price averages without dividends remvested. 


\section{Chart 1}

\section{Levels of Stock Price Indexes $(7 / 1 / 87=100)$ in local currency}
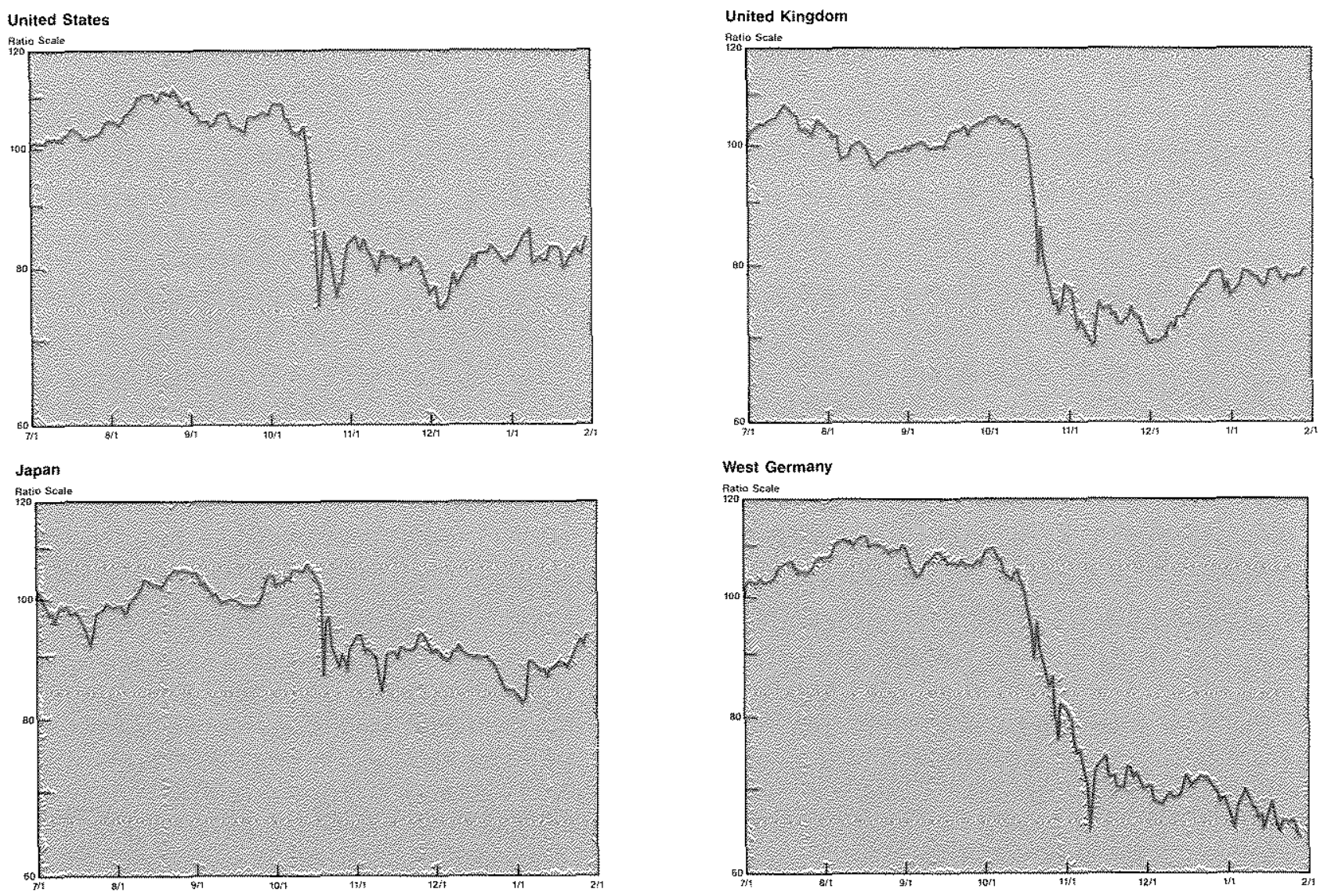

detine a trading day as stating with the opening of the European markets.

The levels of the different indexes, measured in terms of local curency are shown in chart 1 . The behavior of the indexes reveals some common movement during this period, especially around October 19. All of the indexes decline sharply from the middle of October to the end of the month." Before and after the crash, however, there appears to be little common movement in the levels of the indexes.

While the behavion of the indexes in terms of local curency is interesting, the indexes should be measured in tems of some common curency to be directly comparable. Comparing stock prices in the United states in dollars and stock prices in the United Kingdom in pounds is much like mea- suring the price of apples in dolars and pounds and comparing the movements of the fwo. We measure the different indexes in tems of U.S. dollars.

The dollar-denominated indexes in chat 2 show simila pattems to those in chant the differences in behavior of the different indexes since the crash, however, are striking. Based on the data in chat 2, the U.S. and U.K. indexes increase only slightly after the crash, while those in Germany continue to fall. The index for Japan, howeve: retums roughly to its value immediately fol lowing the crash. By January 29, 1988, stock prices in Gemany, the United Kingdom and the United States are still below their October 19 levels. For example, stock prices in the United states at the end of January are about 17 percent lower than on
15 The sizes of the decreases in stock prices in October 1987 differ substantially. The decline in the Urited States was 21.6 percent, slightly below the average decrease of 24.6 percent for a sample of 23 countries. For example, stock prices tell as little as 5.8 percent in Austria and as much as 45.8 percent in Hong Kong (measured in U.S. dollars). For further discussion, see Roll (1988). 


\section{Chart 2}

\section{Levels of Stock Market Indexes $(7 / 1 / 87=100)$ in U.S. dollars \\ United States \\ Unted Kingdom}

Ratio Sials

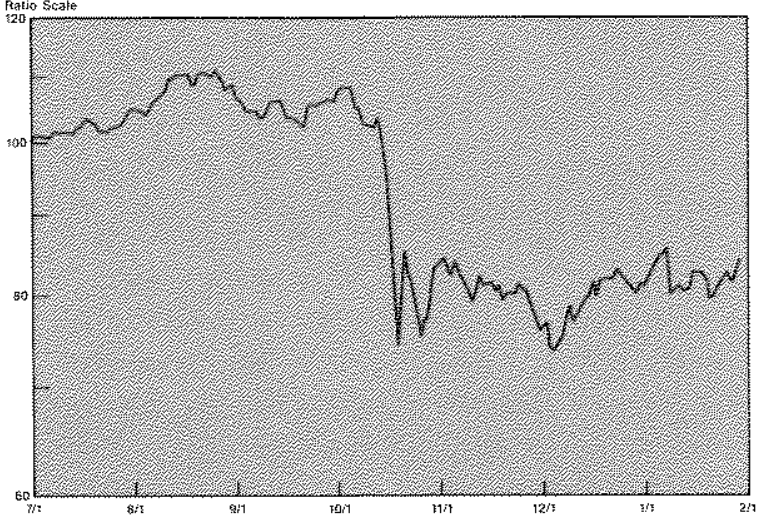

Japan

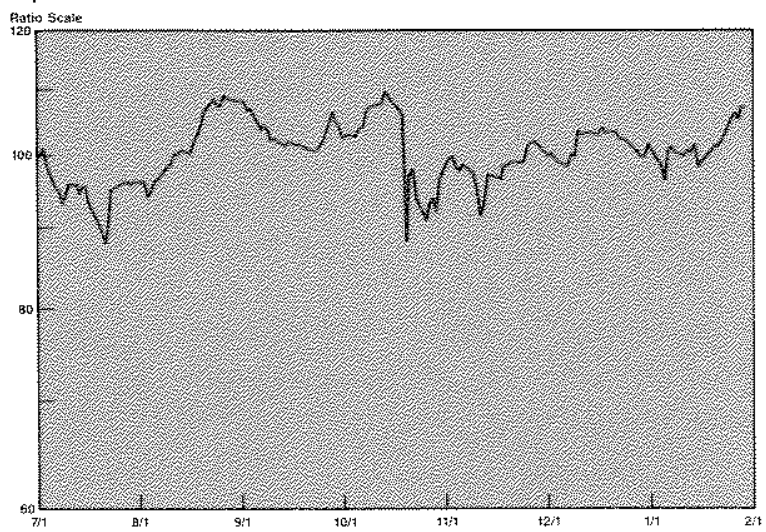

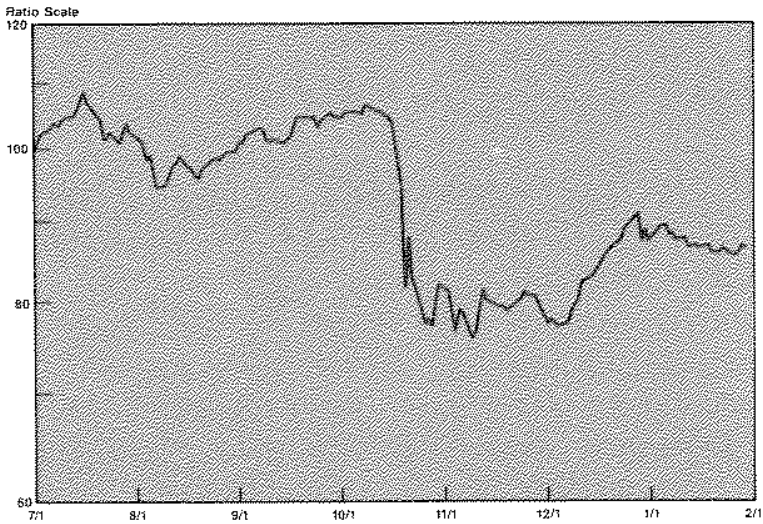

West Germany

Räio Srats

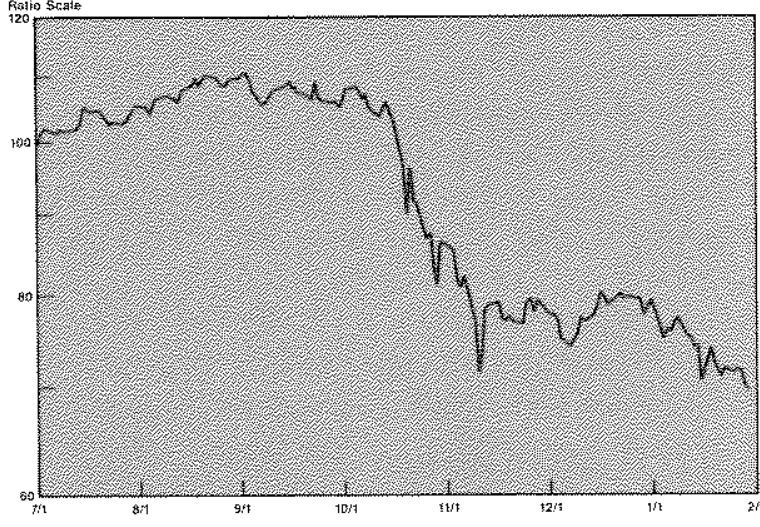

October 12, 1987 - one week before the crash. Similarly, prices in the United kingdom and in Gernary at the end of January are about 18 percent and 33 percent below their October 12 levels. In shap contrast, the Japanese stock market index on January 29 is less than 1 percent lower than on October 12.

Despite these different movements of the levels of stock prices, there is some common behavior in the changes in the different country indexes. $A$ simple way to see this is to calculate the number of days every index increased or decreased. During the seven months covered in chart 2 , there are 20 days when all the indexes increased and 16 days when all decreased itule signiffonce should be altached to the greater number of coincident increases than decteases: with the exception of Germany inereases predominate in each colnty during the period. Coincident increases are more likely than decreases even if the changes are unelated. Some coincident increases and decreases in all of the indexes are expected by chance alone. If the probability of an increase in one counuy is uncelated to events in oher countries. the probability of a coincident increase in all of the indexes is about 7.7 percent, and the probability of a coincident decrease in all of the indexes is about 4.85 perent." This implies that these data would have about 19 davs of coincident movements due to chance alone, substantially less than the actual 36 days with increases or decreases in all four in-

\footnotetext{
16For the data in chart 2, the indexes decrease in 52.7 percent of the days in Germany, 49.0 percent of the days in Japan, 42.0 percent of the days in the United kingdom and 44.7 percent of the days in the Unted States. If the changes are unrelated, the joint probability of conncident decreases is simply the product of the proportions of days with decreases to the total. which is
}

4.85 percent or about 7.2 days. The joint probability of the four indexes increasing or staying the same is about 7.7 percent of about 1.5 days. If the changes in the indexes are unrelated. the total number of days expected to have coincident movements 15 about 18.7 days, with a standard devation of this expected value of about 4.1 days. 
Table 1

Correlations of Stock Price Indexes:

July 1, 1987-January 29, 1988 (logarithms in terms of dollars)

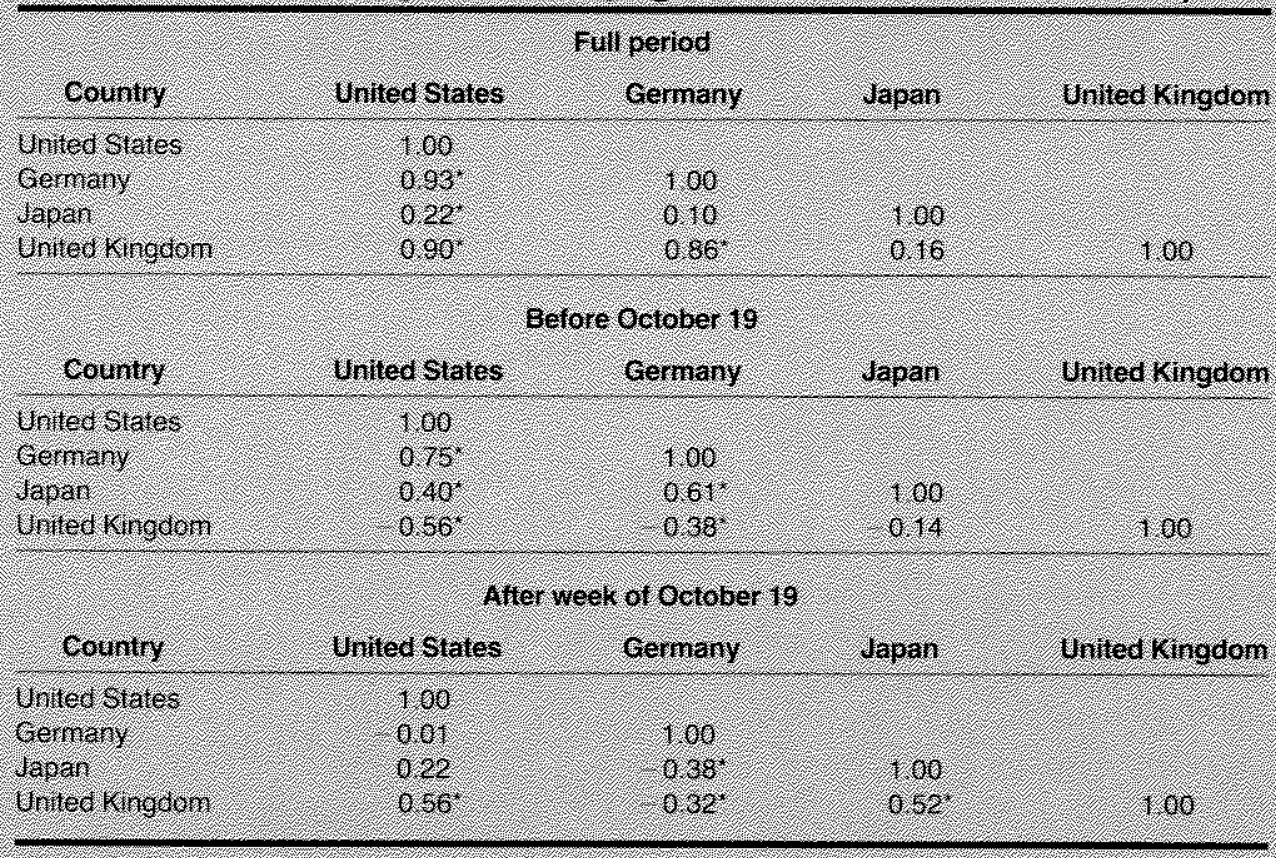

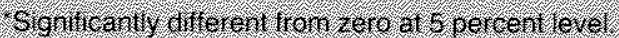

dexes. If the changes across stock markets were unrelated, the probability of observing 36 coincident changes or more would be much less than 1 percent. This suggests that it is likely that changes in the indexes are related.

\section{Cortrentions Among the Levels of Stock Prices}

There does not appear to be a stable relationship among the levels of stock prices table 1 ). Except for Japan, the evidence for the whole period suggests that the indexes are highly correlated. If one examines the comelations of the levels of stock prices before and after the crash, however, the correlations change damaticaly. For example, the correlation of the U.K index with the U.S. in dex is about 0.90 for the whole period. Before the cash, however, the correlation is -0.56 . while, after the crash, it is 0.56 . Conversely, the correla- tions for the U.S. and German stock indexes are 0.93 for the whole period, 0.75 before the crash and -0.01 atterwards

This instability is precisely what one would expect if the relative stock price indexes are ran dom walks with no long-run melationships beween their levels. The negative correlation between the index for the United States and the Lnited Kingdom before October 19, though, is not what would be expected if stock prices around the world were "matcheting upward" before the crash.

\section{Tesis for Unil nors}

We can test whether, as equation 5 implies, the relative stock price indexes have unit roots."

Test statistics to detemine whether the levels of the relative stock indexes have unit roots are presented in table 2. Two periods are analyzed: one uses data from the full period; the other examines
The test essentially consists of implementing the Dickey-Fuller test (1979) on the ratio of stock price indexes. The reported tratios are those on the lagged level of the ratio in the relevant equation. All equations include a constant term and one lagged value of the dependent variable. The critical values for the test ate from Fuller (1976), p. 373.
An alternative interpretation of this test in terms of cointegration as defined by Granger (1986) and discussed by Engle and Granger (1987). Under this interpretation, we are testing whether two stock price indexes are cointegrated with a coeffi. cient of unity in the equation relating the two indexes. 


\section{Table 2}

Test Statistics for Unit Roots in Relative Stock Price Indexes: July 1,1987 -January 29, 1988 (logarithms denominated in dollars)

Full period

\begin{tabular}{|c|c|c|c|}
\hline Gountry & Gernany & Jopan & United Kingadom \\
\hline 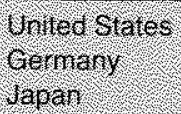 & $+1,67$ & 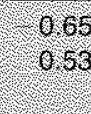 & 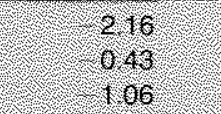 \\
\hline & \multicolumn{2}{|c|}{ Eefore October 19} & \\
\hline country & Gernany & Japan & United Kingdom \\
\hline 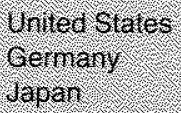 & 103 & $.0,32$ & $\begin{array}{r}040 \\
1,57 \\
1.67\end{array}$ \\
\hline
\end{tabular}

Significany diferent ron zero at 5 percent level

the relationship before the crash. A tratio less than about -2.89 is inconsistent with the hypothesis that the levels of two series have a unit noot. The test statistics in table 2 are well above the 5 percent critical value, consistent with the hypothesis that all of the different relative stock indexes have unit roots. These results provide no reason to expect that, given an increase in the U.S. index, for example, the Japanese index also will rise, or fall. That is, there is no "normal" level of these indexes relative to each other. This is especially important because, in contrast to the conclusion of the Brady Commission, it is inconsistent with the notion that the markets rose as one during 1987 before the crash. Furthermore, it indicates that using the levels of the stock market indexes to judge whether there is any relationship between the markets is fallacious.

\section{Correlutions of Changes of the Tnderes}

The evidence indicates that there is no reliable relationship among the levels of the indexes. Simple correlations of changes in daily stock prices can be used to measure the extent of the association between the rate of increases in the indexes itable 3. For the whole period, the correlations among the changes in the U.S. index and those of the other countries range from 0.64 for Japan to 0.32 for Gemany. The correlations among the indexes for Gemany, Japan and the United Kingdom range from 0.56 to 0.15 . At the 5 percent mar ginal significance level, all but the Japan/United Kingdom correlation are different from zero.

These correlations are, on average, noticeably lower when the week of the crash in prices is excluded from the correlations. Correlations without the data for the week of October 19 are presented in the lower part of table 3 . All but two are lower than those for the whole period. The only higher comelation for a subperiod is the correlation between changes in the Japanese and German stock indexes, a correlation of 0.22 excluding the week of the crash and 0.21 for the whole period. 'These results are consistent with the notion that movements in the indexes, unlike levels of the indexes, are indeed related.

\section{Summary of the Short-Temn Pesulls}

The daily data for the period around the october 1987 crash provide little support for the notion of prices ratcheting up or down together. Rather, they indicate that there is no constant relationship between the levels of the indexes. There is, however, a positive relationship among changes in the indexes, a finding consistent with the view that either financial transactions or international trade of goods and services affect the different indexes in the same direction.

\section{STOCK PIIGE INDEXES SINCE 195\%: A LONGERTRUN VILW}

Investigating the link between stock markets using monthly data spanning the past 31 years provides a useful perspective on the preceding results. Chart 3 shows monthly average indexes of industrial share prices for each of the four countries for 1957 through 1987. Al stock price indexes are denominated in terms of U.S. dollars." $\mathrm{Al}$ though changes in stock prices like those in October have been quite rare during the past few de- ts The monthly data are from the International Financial Statistics (IFS) data tape of the International Monetary Fund. The U.S. data are the monthly averages of the daily close of 400 Standard and Poor's industrials on the NYSE, the figures for Germany are the averages of daily quotations covering 95 percent of common shares of industrial companies headquartered in Germany, the Japanese data are the averages of dally closing prices for all shares traded on the first section of the Tokyo exchange and the U.K. data are the average of daily quotations of 500 industrial ordinary shares on the International Stock Exchange in London. The exchange rates used to convert the stock indexes into dollars are the monthly average rates from the IFS data tape. 
Table 3

Correlations of Changes of Stock Price Indexes: July 1, 1987-January 29, 1988 (changes of logarithms in terms of dollars)

\begin{tabular}{|c|c|c|c|c|}
\hline country & United Stares & $\begin{array}{l}\text { Period } \\
\text { Germany }\end{array}$ & Japan & Grited King don \\
\hline 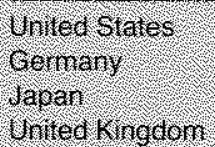 & $\begin{array}{l}1,06 \\
0.6 \\
064 \\
0.6\end{array}$ & $\begin{array}{l}100 \\
021 \\
056\end{array}$ & 10.06 & \\
\hline & Bele & or octo: & & \\
\hline couniry & United stares & gerriany & Japan & United Kingdori \\
\hline 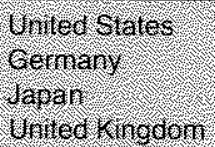 & $\begin{array}{r}(100 \\
0,21 \\
0,28 \\
0.46\end{array}$ & $\begin{array}{l}1.10 \\
0.28 \\
0.66\end{array}$ & 8.12 & 100 \\
\hline
\end{tabular}

Sicrificanty diferent fron reto ats petcent vevel.

\section{Chart 3}

Stock Price Indexes (monthly averages, $1980=100$ ) in terms of dollars

United States
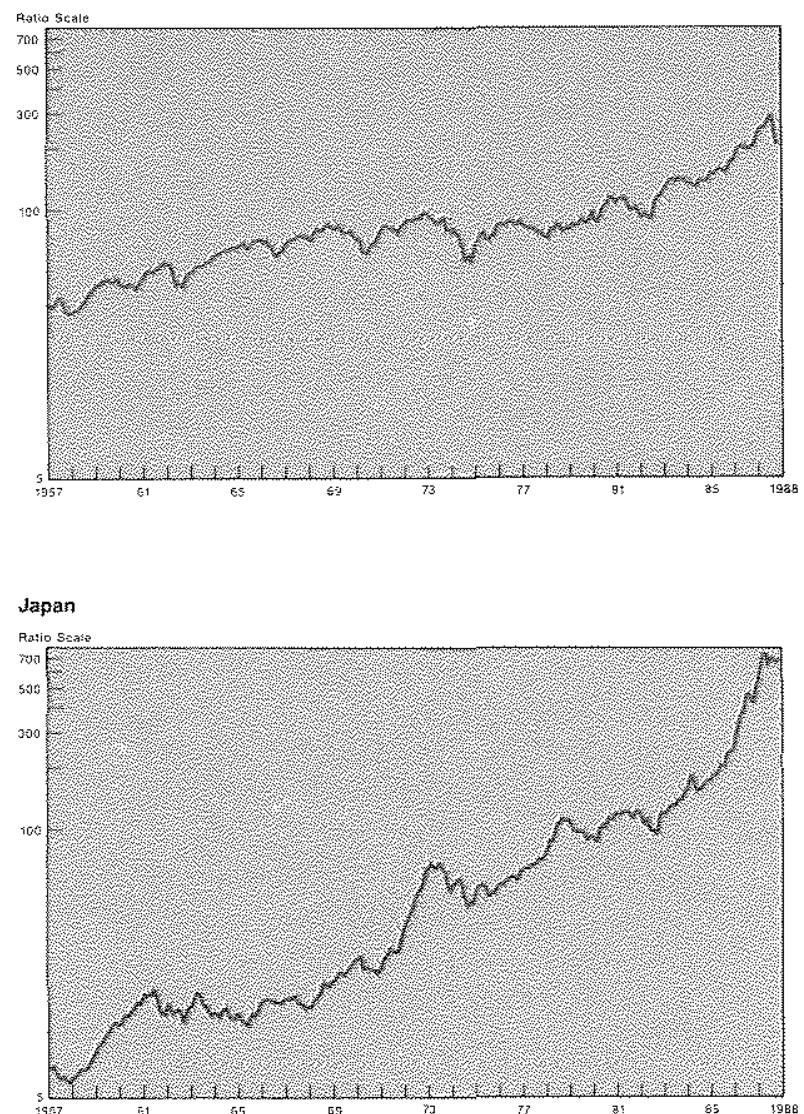

United Kingdom
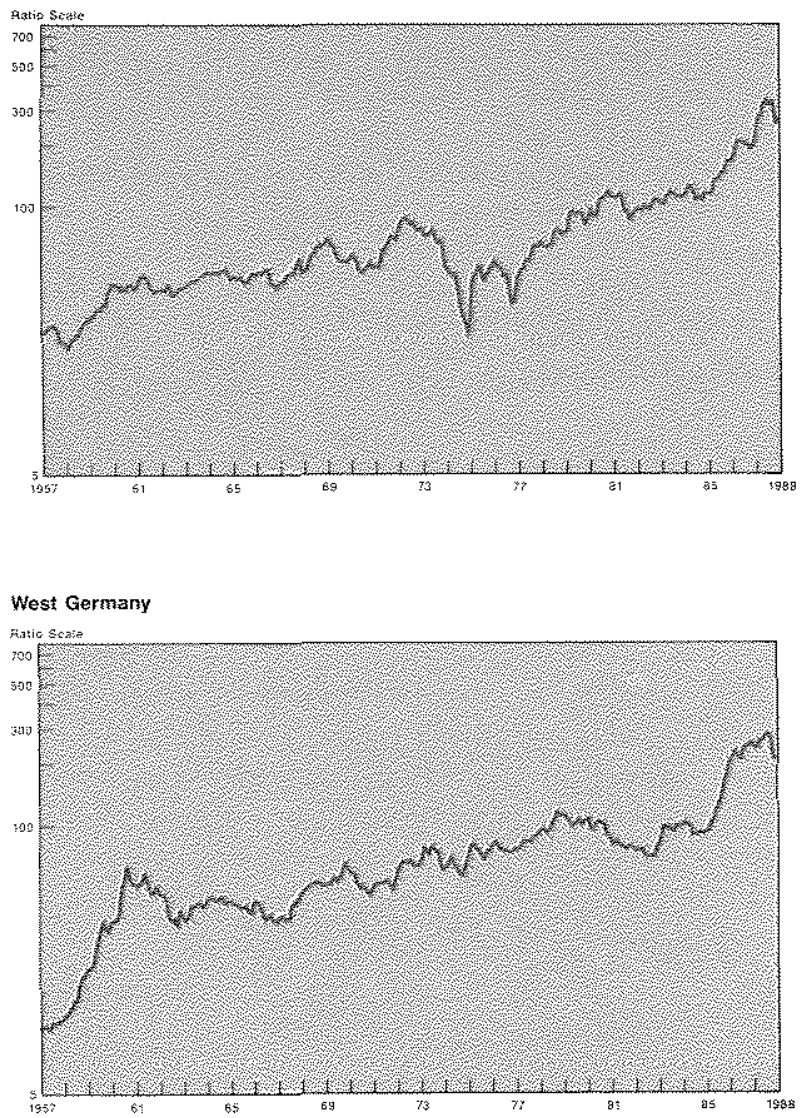
cacks, substantial decreases in the market indexes are not uncommon. For example, stock prices in the Inited States decreased by relatively lage amounts in several months: the index decreased 12.0 percent in June $1962,11.6$ percent in May 1970 and 10.5 percent in September 1974 . The decrease in October 1987 , on a monthly average basis, was 13.3 percent. Large single-month increases are not exactly unknown either: the index for the United States increased 12.1 percent as recently as September 1982.

It also is interesting to note from chart 3 that stock price decreases in the different makkets often coincide. Fom 1957 though 1987 , stock prices declined in all four of the makets in 31 months. Coincident increases occur more frequenty during the sample: all four stock price indexes increased in 79 months. How many of these would be expected by pure chance? The average proportion of months with an increase is about wo-thinds for each county. If two-thirds is the probability of an increase, the foint probability that all of the indexes would increase in any month is 19.75 percent. Given our sample of 371 months, this means that about 73 months of coincident increases are expected. Since one-third is the average proportion of declines for each country, the expected number of coincident decreases is about five. Hecause the sample contains 110 months of coincident changes while only 73 would be expected by chance, this is longer-term evidence that coincident changes in the indexes occur more often than would be expected by chance.

\section{Relationship Between the Levels of Stock Prices}

Is there a long-term relationship between the levels of stock prices during the past 31 vears? To answer this, monthly data are used to test for unit roots in the relative stock price indexes. The resuls of these tests are presented in table 4 : The top pane of the table reports the relevant test statistics for the full period. The evidence indicates that the relative stock price indexes have unit rools. Wib 371 monthly changes, a t-ratio less than about -2.88 would be inconsistent with the null hypothesis of a unit root at the 5 percent significance level. The t-ratios generaly are greated than the critical value, an outcome inconsistent

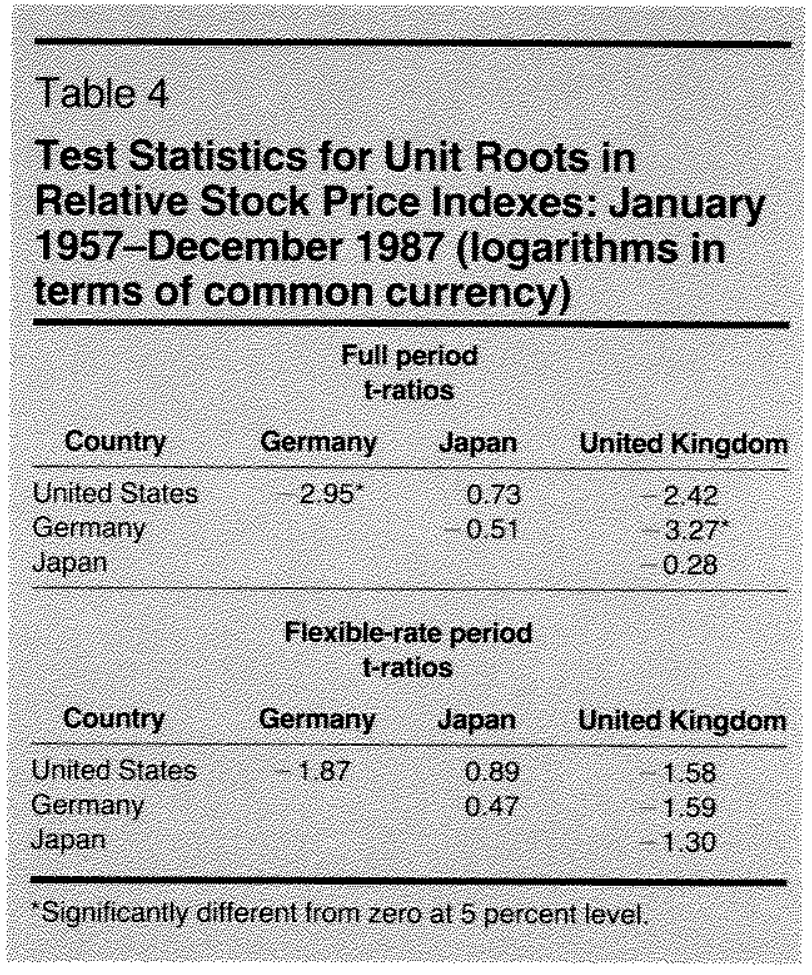

with the existence of any nomal long-un level of these indexes relative to each other. The test statistics for Getmany relative to the United States and for the United Kingdom relative to Gemany are, however, less than the critical value. Unlike the others, these results are consistent with the notion that these indexes tend to some nomal level.

The results of the unit root tests from the flexible-rate period, a period chatacterized by greater financial integration across national bor ders than the fixed-nate period, uniformly are greater than the critical value ${ }^{2}$ Test statistics using the data from the flexible-rate period are presented in the bottom panel of table 4 . These results indicate that in every instance the relative stock pice indexes have a unit toot. The empirical evidence from the flexible-rate period clearly is inconsistent with the notion that the levels of stock market indexes are linked across countries over long-run periods.

\section{Cortrelations of changes of the Inderes}

Corfelations of the changes in the logatithm of the monhly stock price indexes are reported in
19 In order fo allow for the first-order serial correlation in the indexes due to the Working (1961) effect, we include one lagged change of the reative index in the regressions. We make no adjustment to the critical value for this estimated coeflicient. 25The beginning of the flexible-rate period is defined as April
1973 . 


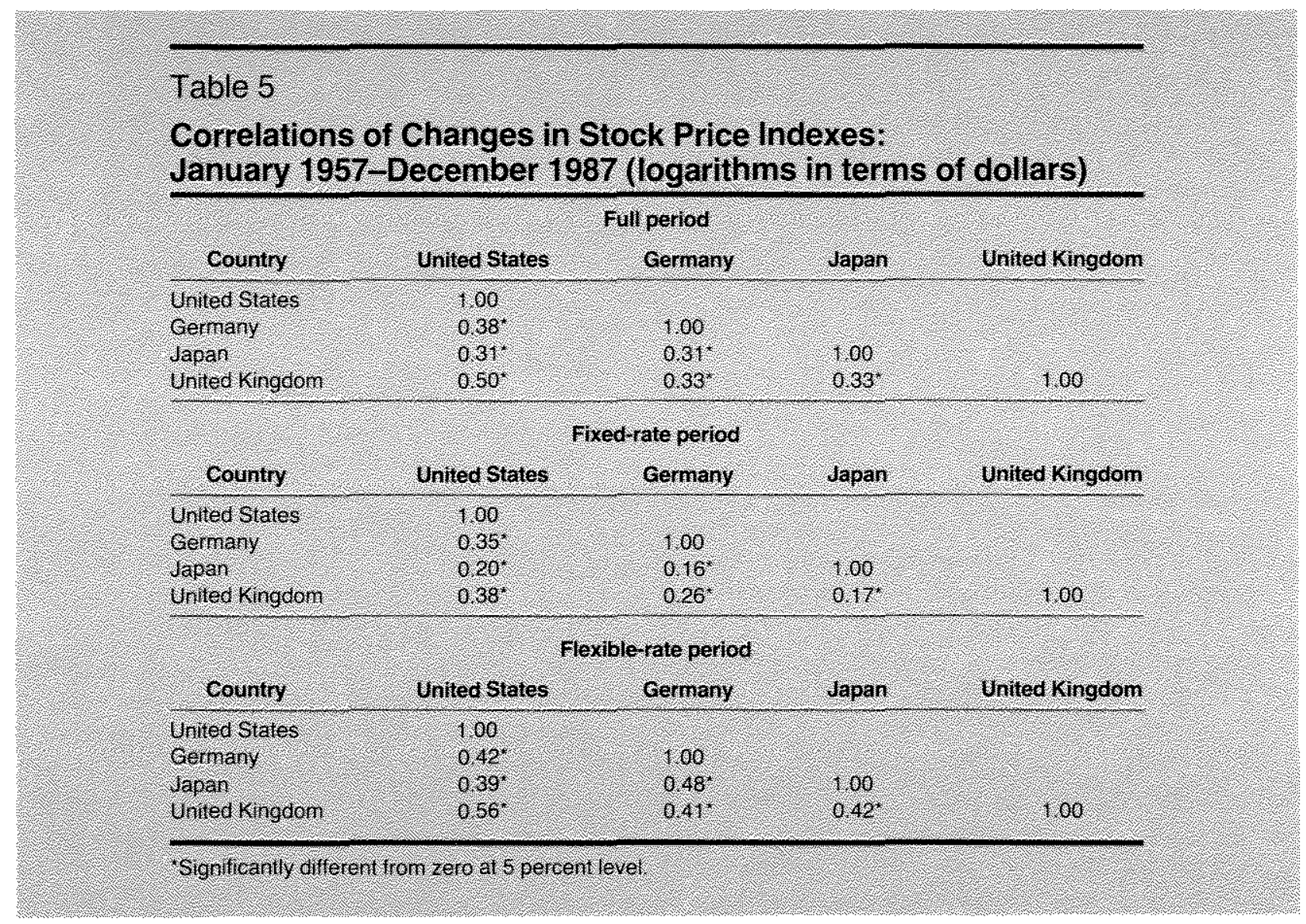

table 5. Because the sample period incorporates both the fixed-and flexible-exchange-rate regimes, the correlations are calculated for the full 31 years and for each of the two exchange-rate regimes. The full period correlations are relatively high across markets, and all are statistically significant. All but one of the correlations is between 0.31 and 0.38 . The outlier is the higher correlation of 0.50 between the United States and United Kingdom.

The evidence from the fixed-rate period presents a rather different picture. Although the correlation between changes in the German and U.S. indexes is about the same as the correlation for the whole period, the other correlations are much smaller. For example, the correlations between the stock price indexes for Gemany and Japan (0.16) and between Japan and the United Kingdom (0.17) are about one-half the size of their correlations for the full period. There also is a noticeably lower correlation between the U.S. and Japanese indexes, 0.31 for the full period and only 0.20 for the fixed-rate period

The evidence from the flexible-rate period suggests that the relationship between U.S. stock prices and the foreign markets is somewhat closer relative to the fixed-rate period. The largest increases in the correlation are between the Japanese and the other indexes, and the largest of these changes is between the German and Japanese indexes, which increases from 0.16 during the fixed-rate period to 0.48 during the flexiblerate period. The correlation between stock price changes in Japan and those in the United States and the United Kingdom also increases substantially, from 0.20 to 0.39 , and 0.17 to 0.42 , respectively. This suggests that the markets are more integrated in the latter hall of the period:"
'Controls on financial transactions were not suddenly axed with the breakdown of fixed exchange rates: instead, they have been lifted gradually with each passing year. This suggests that, if changes in these restrictions account for at least part of the increases in these cotrelations, the correations should be even larger for a period beginning later than 1973 . Correlations for 1980 through 1987 provide a tentative way of examining this issue. These correlations provide modest support for this hypothesis, with two of the correlations greater for the more recent period relative to the results for the flexible-rate period in table 5. 


\section{CONCUESOE}

Are stock nakets linked acmoss conntres? The levels of stock price indexes in different markets need not move closely together; indeed, they do not. Daly data for thee months before and after the October 1987 crash and monthly data for the past 31 vears show no evidence that the levels of indexes for the United States, Japan, Gemany and the United Kingdom are related. This means that the levels of indexes show no tendency to return to any particulat value relative to each other. Thus, using different levels of indexes in various countries as evidence of a link or lack thereof between the mathets is unfounded.

The changes in the stock price indexes, at least in the four markets that we examine, generally do move together. The tightness of these links, while real is nol exceptional. For example, the correlation of monthy changes in slock prices in the United states and the Unted Kingdom is about 0.56 based on data since the beginning of flexible exchange rates. While significantly different from zero, this correlation also is quite far from one.

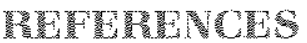

Bryant, Ralph C. Intemational Financial Intermediation (Brookings Institution, 1987).

Cho, D. Chinhyung, Cheol S. Eun, and Lemma W. Senbet. "International Arbitrage Pricing Theory: An Empirical Investigation," Journal of Finance (June 1986), pp. 313-29.

Cooper, Richard N. "The United States as an Open Economy," in R. W. Hater, ed. How Open is the U.S. Economy? (Lexington Books, 1986), pp. 3-24.
Cowan, Alison Leigh. "Global-Market Notion is Dispelled in Quarter," New York Times, April 4, 1988, p. D8.

Dickey, David A., and Wayne A. Fuller. "Distribution of the Estimators for Autoregressive Time Series with a Unit Root," Joumal of the American Statistical Association (June 1979). pp. 427-31.

Engle, Robert F., and C. W. J. Granger. "Co-integration and Error Correction: Representation, Estimation, and Testing." Econometrica (March 1987), pp. 251--76.

Fuller, Wayne A. Introducfion to Statistical Time Series (Johr Wiley and Sons, 1976).

Granger, C. W. J. "Developments in the Study of Contegrated Economic Variables," Oxford Bulletin of Economics and Statis. tics (August 1986), pp. 213-28

Malkiel, Burton G. A Random Wak Down Wall Street, 4th ed (W. W. Norton \& Company, 1985)

Muth, John. "Rational Expectations and the Theory of Price Movements:" Econometrica (July 1961). pp. 315-35.

Presidential Task Force on Market Mechanisms. Report (Janu* ary 1988).

Roll, Richard W. "The International Crash of October 1987:" in Robert Kamphuis, Roger Kormendi, J. W. Henry Watson. eds., Black Monday and the Future of Financial Markets (Mid America Institute, October 1988), pp. 35-70.

Santoni, G. J. "The Great Bull Markets 1924-29 and 1982-87: Speculative Bubbles or Economic Fundamentals?" this Review (November 1987), pp. 16-30.

Santoni, G. J., and Gerald P. Dwyer, Jr. "Bubbles or Funda. mentals: Some Evidence from the Great Bull Markets of 1924-29 and 1982-87, "paper presented at the Conterence on Crashes and Panics in Historical Perspective, Salomon Brothers Center for the Study of Financial institutions, New York University, October 1988

Solnik, Bruno H. "The International Pricing of Risk: An Empitical Investigation of the World Capital Market Structure." Joumal of Finance (May 1974), pp. 365-95.

Working, Holbrook. "Note on the Correlation of First Differences of Averages in a Random Chain," Econometrica (October 1960), pp. 916-18. 